\title{
RECONSTRUCTED COLOPHON IN THE TEXT OF THE SYRIAC JULIAN ROMANCE AS A CLUE TO THE MYSTERY OF ITS AUTHOR
}

\author{
Alexey Muraviev \\ NATIONAL RESEARCH UNIVERSITY \\ HIGHER SCHOOL OF ECONOMICS
}

\begin{abstract}
The so-called Syriac Julian Romance is preserved in two manuscripts from the British Library, BL Add 14641 (6th c.) and BL Rich Rich 7192 (9th c.). T. Nöldeke was first to propose the idea that the mss. constitute one literary piece. However it consists of three different stories which were copied from different protographa. The story of Eusebius was written by a certain deacon Epainetos of whom only a rubric survived in the text. However the story of the Persian expedition of Julian the Apostate is a different case. It is possible that it has preserved parts of the original colophon from the protograph at the beginning and at the end of the Expedition narrative. The first part of this 'circum-colophon' introduces the abbot 'Abdel and his addressee certain Apolinarius. At the end we see what has remained from the colophon and that is written by Apolinarius himself. This circular structure could be called circum-colophon in the sense that it frames the single literary piece, which once formed a manuscript. In this article the structure of the colophon is exposed and the explanation for the person of Apolinarius is proposed. In addition the colophon of the Sinai Arabic version of the same text is analyzed.
\end{abstract}




\section{TEXT AND MANUSCRIPT HISTORY}

The so-called 'Syriac Julian Romance'1 has been preserved in two Syriac manuscripts from the British Library, BL Add 14641 (6 ${ }^{\text {th }} \mathrm{c}$.) and BL Rich 7192 ( $9^{\text {th }}$ c.). ${ }^{2}$ Both manuscripts were copied in Egypt. Add. 14641 was brought to London by Tatttam and is one of the most ancient Syriac manuscripts known at the present time. The idea that they constitute a unique piece was not obvious. The texts contain the story of the last pagan Roman emperor and his desperate attempt to imitate Alexander the Great in conquering Persia. It was also unclear where and when the original text was composed. Th. Nöldeke, to whom W. Wright sent a note about the manuscript, published two articles about $i^{3}$ and entrusted the edition to his disciple, J. G. Hoffmann. ${ }^{4}$ His primary thesis, which has been challenged several times since its publication, was based on the unity of the two pieces. The great German Semitic scholar thought that the 'Romance' was written in Syria in the early $6^{\text {th }} \mathrm{c}$. CE. Nöldeke's idea was also based on a particular assumption about the nature of the text. ${ }^{5} \mathrm{He}$ called it a 'Romance', meaning that it was a pure fiction. Later his views were criticized by Han Drijvers, who launched the idea that the 'Romance' is a piece of anti-Jewish polemical literature. ${ }^{6}$ Finally, Michel van Esbroeck described the nature of the text as hagiographic. ${ }^{7}$ It consists of three pieces: the story of apostasy and the first steps of Julian (called oreda) in Constantinople. ${ }^{8}$ The story about the legendary bishop Eusebius of Rome constitutes the second part. ${ }^{9}$ The third part contains the story of Julian's expedition to Persia and his death. It is the third part that is present in the oldest manuscript and has an interesting feature: it is a separate text preceded with a

${ }^{1}$ Drijvers 1994; Muraviev 1999; Drijvers Jr 1999.

${ }^{2}$ Wright 1872, no 918, 1042-1044.

${ }^{3}$ Nöldeke 1979, Nöldeke 1979a.

${ }^{4}$ Hoffmann 1880.

5 Nöldele 1879, 291: “im Ganzen kann das Buch, auch rein als Roman gefasst, keinen hohen Rang beanspruchen."

${ }^{6}$ Drijvers 1994, 212.

${ }^{7}$ Esbroeck, van 1987.

8 The $\mathrm{CPl}$ story was reproduced in the Chronicle of Se'ert (cf. Muraviev 1999, 203-204, Scher, Dib 1907) and some Georgian hagiography (Kekelidze 1945).

${ }^{9}$ It is connected to the Invention of the Cross cycle. 
title and ending with a kind of colophon. In this brief article, I will try to show that this 'circum-colophon' was copied from the original manuscript of the lost chronicle.

\section{EXPLICIT OF THE EUSEBIUS STORY}

Neither ms. of the Romance includes a colophon of the scribe, but inside the story there is a 'circum-colophon', which to my mind reflects the original colophon of the author and first scribe. The story of the bishop Eusebius, who opposed the Apostate trying to build a pagan altar in the city is based on the bypomnemata of the deacon Epainetos or Aphantos or even Penētos (orłiar). It ends with a sort of explicit in red ink saying:

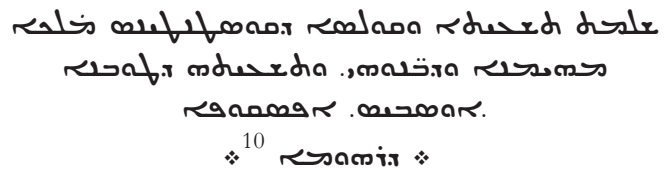

Finished the life and the panegyric of Constantine the believing king and his sons and the Life of the blessed Eusebius the bishop of Rome.

There is no further sign of the scribe, author, or compiler of the story, Epainetos (?). What was the protograph of the Eusebiusstory? I tend to think it was some copy of Epainetos' memoirs. It did not contain any colophon, and what we have is a rather literary ending reflecting a typical hagiographic procedure of reshaping evidence in view of the pedagogical task. ${ }^{11}$

\section{CiRCUM-COLOPHON OF 'ABDĒL}

However, the story that follows-that is, of the Persian expedition-begins with the letter written by a certain abbot 'Abdēl

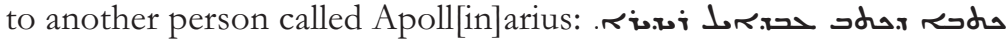
له rdäal' ("The writing written by 'Abdell the archimandrite to the pious Apoll[in]arius, the minister (mhaymanna of Jovian the king to whom was entrusted the deed of the [peace] treaty between the two kingdoms" [i.e. Rome and Persia]). This

10 Add 14641, fol. 31r, ed. Hoffmann, 1881, p. 59.

${ }^{11}$ Esbroeck, van 1987, 201-202; Reinink 1992. 
looks like an incipit of a new piece, which represented the first part of circular structure in the letter. It is tempting, then, to consider it as not as a fictitious colophon but as the first part of the colophon surrounding the original story. This is based upon the fact that by chance we know the author of the written source used for the Persian expedition story.

The name of a mysterious Abdēl appears for the first time in the text on the fol. 31r. After the letter of the archimandrite finishes, there begins the story of Jovian, the general in the army of the Apostate and a secret Christian. It seems that Apolinarius does not come up any more. However, there is one more place when these names occur in the text of the Julian Romance. So the letter continues in the second part (or the 'second Romance' as Nöldeke called it) found in the ms. Rich 7192. On fol. 51 $\mathrm{r}$ a continuation of the circum-colophon with the same 'small servant of Christ' Apoll[ina]rius, this time 'writing on the request of 'the illustrious and beloved by God mār 'Abdēl the archimandrite of the city (mahōza) of SNDRWN':

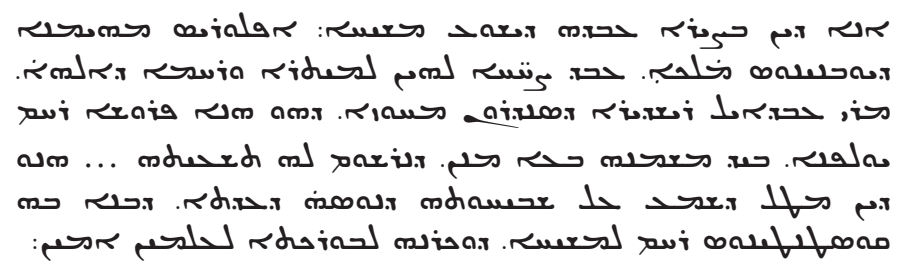

This passage looks like an ending of the book if not the colophon of the original manuscript. The main interesting point of it is a hapax name nirso, probably reflecting the semiticised form of Alexandria - al-Iskenderiyya ${ }^{12}$ However, this is not the colophon of the whole 'Romance', because on fol. $57 \mathrm{v}$ the text ends with an ordinary colophonic fragment:

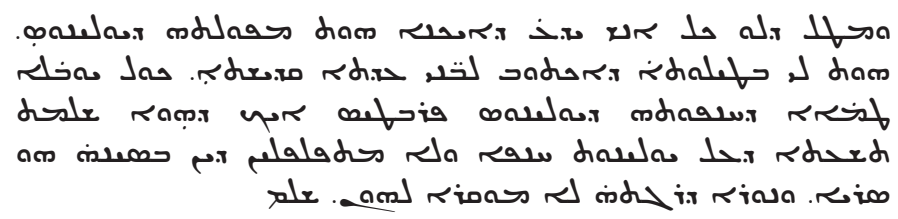

12 Van Esbroeck thought that it is a form of Sanatruk or $\Sigma \iota v a \theta \rho \omega ́ \pi 0 \lambda ı$ but it seems improbable. 
Because not every man knows how the fall of Julian occurred, I (whoever was this lay - A.M.) have found occasion to write for the Sons of the Holy Church the whole grim account of the paganism of Julian the Transgressor (Parabates from Greek cf. the Arabic usual form البرباط and how the history of Julian the pagan ended, so that they will not be infected with his putrid filthiness, and that the fire of his desire [for paganism] will not set them on fire. The end.

This circular structure could be called circum-colophon in the sense that it frames the single literary piece, which once formed a manuscript. Here the colophon is used as a literary mean or device to make the Persian War Chronicle part of the hagiographical 'Romance'.

\section{EXPLANATION OF THE NAME APOLLINARIUS}

There are several points to observe regarding the name Apollinarius. First, Apollinarius (Apōlōrīs's) in the Arabic version preserved in the Sin. Arab. 516 is called Ilia (ايليا), which is a transformation typical for Arabic, and he is called a 'minister' or a confidant (mbaymana a) of Jovian. Second, he is writing the letter for the abbot 'Abdēl, which contains the story about Jovian and the Persian war. This Abdēl (or Gabriel, as it is spelled in the Arabic translation of the SJR in Sin. Arab. 516) is an abbot in Sanadrōn, Arabic سندرون. Third, all manuscripts containing the 'Romance' originate in Egypt; the Arabic translation was also kept in St Catherine monastery on Mt. Sinai.

It is possible to propose an explanation for these observations. Apollinarius is in fact the same person as Eliazar, reported by Movsēs Khorenac'ín, Hist. Arm. II, $70 .{ }^{14}$ In the History Movsēs (or whoever was the author of $\mathrm{it}^{15}$ ) used the library of many volumes, and a Greek Chronicle of the Persian war among them. The author was a Persian convert from Mazdeism, who was a minister of the

${ }^{13}$ Spelled differently in the mss. In 1928 Herman Gollansz published in London a very raw translation from Hoffmann's text where he used this transliterated form.

14 Abełean, Yarut iwnean 1991.

15 Thomson 1978, 12-17. 
emperor Jovian called in Persian Khoroh-boht (Armenian: Hořobūt) or Ełiazar by his baptismal name. ${ }^{16}$ Movsēs does not say anymore and the original Greek chronicle was obviously lost. The name thus varies from Eleazar to Apolinarius or Elias.

My hypothesis is that the lost Greek chronicle has been preserved very early (in the beginning of the $6^{\text {th }}$ c.) in the Syriac version, and the phrase quoted above was its colophon. It is possible also that the same man (Apollinarius-Eleazar) as a Persian knew Syriac, the lingua franca of the Middle East, and translated into Syriac the story of which he was an eye-witness. Movsēs tells us that he wrote it originally in Greek. Then, he would have added to his translation the Life of Eusebius, surrounding it with two colophons. His addressee, 'Abdēl (or Gabriel), was an abbot of Dayr as-Suryān or some monastery in Egypt near Alexandria. In the 'Romance' there is a mysterious Persian priest very close to Šahpuhr, by name Aryā-mihr (Syr. imsin or ims in, which by that time was certainly read as Arīmīhr). ${ }^{17}$ In Arabic this is rendered as ارمهان, which is a result of misreading: Arīmīhr was first read as ارمهار, Ar-mihār and then changed to Armihān by adding a dot to the letter $\mathrm{ra}$, making of it nun. This person played an important role in the secret relations between the Christian general Jovian and the Persian court, which aimed at a peace conclusion. This Arimihr secretly converted to Christianity. There is some probability that it was, in fact, the Persian mobēd Hwarra-bokht baptized under the name Eleazar known to us from Movsēs, who portrayed himself under the faked name Arimihr. One cannot exclude the possibility that he changed his Christian name to Apollinarius to make the anonymity complete, or just because he took a monk name after a tonsure. This could explain the difference in the names between the lost Chronicle and the Syriac hagiographical 'Julian Romance'. The Syriac circum-colophon in the manuscript is thus a trace of an older compositional layer: the compiler made the letter by Eleazar/ Apollinarius an integral part of his narrative.

16 The names are IUnnnpnun and Enhuquup; Thomson 1978, 10.

${ }^{17}$ Justi 1895, 25. 


\section{ARABIC TRANSLATION, ITS COLOPHON AND ITS CONNECTION TO THE SYRIAC}

Finally, we should take into consideration the Arabic abridged version of the same 'Romance' from Sin. Arab. 516 and Mingana Arab. Add. 143. ${ }^{18}$ Although not in Syriac, this version represents an early translation from the Syriac. The second ms. preserved in the Mingana collection in Selly Oak contains on fol. B, lines 11-14, an Arabic colophon with one strange particularity the date (year) written in Coptic.

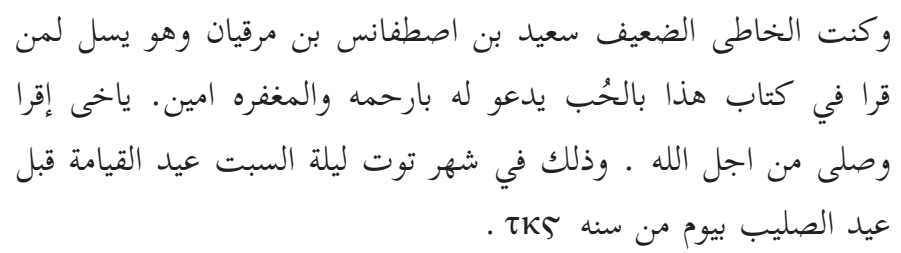

I wrote it, a sinner and weak man, Sa'id ibn 'Stefanos bin Marqiyān, and this is what is asked from whoever reads it with love [in] ${ }^{19}$ this book that he should ask for him mercy and forgiveness. Amen. O, my brother, read and pray for God's sake. It is in the month Toth in the Saturday night of the feast of the [consecration of the Church of] Resurrection $^{20}$ on the eve of the feast of the Cross, on the day of the year 326 .

From this colophon, we may conclude that the Syriac original was kept in Egypt, whence the Coptic numbers. The date is 326, but it is given according to the Coptic chronology and should be either Martyrs Era (+ $284=710$ AD, which is fairly impossible) or the Alexandrian era and thus 938 AD. ${ }^{21}$ The translation was obviously made from the Syriac original before it was dismembered and copied. It consisted of three stories: Constantine and his death

18 Ben Horin 1961; Kāmil 1951.

19 Ben Horin noted the syriacism: b- with the verb كتب, a feature which is not common.

${ }^{20}$ Ben Horin explained appropriately that the قيامة is not (as Mingana thought) the Easter.

${ }^{21} \mathrm{U}$. ben Horin, in his article, read the date inaccurately: he took $\mathrm{K}$ for I and got 316, which is 928 AD. Nevertheless, his reasoning (aside from that mistake) is correct in general. The kappa is very narrow. 
with the apostasy of Julian; Rome and Eusebius; the Persian expedition.

To sum up: by the end of the $4^{\text {th }} \mathrm{c}$. CE, a Persian mōbed (high priest of Mazdeism), Eliazar, wrote the story of the Persian war, in which he called himself Apollinarius, sent it to the abbot 'Abdel, and ended it with the colophon. The story with the circumcolophon was certainly a part of the protograph. Add 14641, which is the earliest evidence containing the Syriac text of the Chronicle, is dated according to palaeographical criteria to the $6^{\text {th }} \mathrm{c}$. The distance between it and the presumed protograph should be estimated as roughly 100-150 years. The circum-colophon was then integrated into the structure of the hagiographic cycle conventionally called 'Julian Romance'. It is thus the only surviving vestige of the manuscript with the Chronicle of Hwarra-bokht. It was written in Greek, later mentioned by Armenian historian Movsēs (between $5^{\text {th }}$ and $7^{\text {th }}$ c.), and after it was translated became part of the famous Syriac literary text. The translation into Arabic completed the story of these transformations, of which the colophon written by Sa'id son of Stephen is the last survivor.

\section{Bibliography}

\section{Sources}

Abełean, Yarut iwnean 1991 = Abełean, M., and Yarut iwnean S. Movsès Xorenaci, Patmutiwn Hayoc [Movses Khorenatsi, History of the Armenians]. Erevan, 1991.

Hoffmann 1880 = Hoffmann J.G.E. (hrsg.) Julianos der Abtrïnnige. Syrische Erzäblungen (Leiden, 1880)

Gottheil 1906 = Gottheil R. A Selection from the Syriac Julian Romance (Leiden, 1906)

Scher, Dib 1907 = Scher, A., Dib, P. (ed.) Histoire nestorienne (Chronique de Séert). Paris, 1907. (PO V (2)).

\section{Secondary literature}

Ben-Horin 1961 = Ben-Horin. U.. An unknown old Arabic translation of the Syriac romance of Julian the Apostate. // Studies in Islamic History and Civilisation. / U. Heyd (ed.) Hebrew university, Jerusalem, 1961. 
Drijvers 1994 = Drijvers H.J.W. "The Syriac Romance of Julian. Its Function, Place of Origin and Original Language" // Symposium Syriacum VI. Roma, 1994. (OCA 247) 201-214.

Drijvers Jr 1999 = Drijvers J. W. "The Syriac Julian Romance. Aspects of the Jewish-Christian Controversy in Late Antiquity," in: H.L.J. Vanstiphout (ed.), All those Nations... Cultural Encounters within and with the Near East. Studies presented to Han Drijuers at the occasion of his sixty-fifth birthday. Groningen 1999, 31-42

Esbroeck van 1987 = Esbroeck van, M. "Le soi-disant Roman de Julien Apostat” // Symposium Syriacum V. Roma, 1987 (OCA 229) 191-202.

Justi $1895=$ Justi F. Iranisches Namenbuch. Marburg, 1895, Hildesheim, 1963j

Kāmil 1951, Kāmil M. Fihrist Maktabat Dayr Sant Katarin bi-Tur Sayna. Kairo, 1951, 2 vols.

Kekelidze 1945 = Kekelidze K., o3mosбjl пmаsбo з3змпо

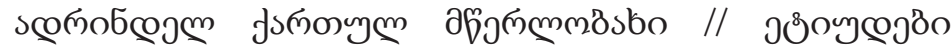

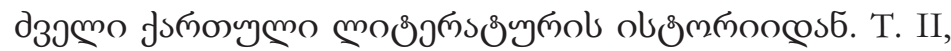
Tbilisi, 1945. 70-80.

Muraviev 1999 = Muraviev A. "The Syriac Julian Romance and its place in Literary history" // XB 1 (1999) 194-206.

Nöldeke 1879 = Nöldeke T. "Ein zweite syrischer Roman über Julian” // ZDMG 28 (1879) 660-674.

Nöldeke 1879a = Nöldeke T. "Über den syrischen Roman von Kaiser Julian” // ZDMG 28 (1879) 263-292;

Reinink 1990 = Reinink G. J. "The Romance of Julian the Apostate as a source for seventh century Syriac apocalypses" / La Syrie de Byzance l'Islam. Actes du colloque international, Lyon-Paris 11-15 septembre 1990 / P. CANIVET (Damas, 1992) 75-86

Thomson $1978=$ Thomson R. Moses Khorenats'I, History of the Armenians. Cambridge, London, 1978.

Wright 1872 = Wright W., Catalogue of the Syriac Manuscripts in the British Museum. London, 1872. 
